\title{
Batik-craft tourism's Competitiveness in Madura, Indonesia
}

\author{
Hengky, S.H. \\ Universitas Bina Darma, Prasetiya Mandiri \\ Tel: 62-896-5704-5738_E-mail: hengky_halim@yahoo.com.au
}

Received: June 26, $2018 \quad$ Accepted: Sep 9, $2018 \quad$ Published: October 1, 2018

doi:10.5296/jmr.v10i4.13623 URL: https://doi.org/10.5296/jmr.v10i4.13623

\begin{abstract}
Batik craft industry in Madura faces the challenge to ACFTA - CEPT, in the form of cheaper price and mass production craft quality. While, the craft industry in Madura still maintain the uniqueness and shades of local culture. This mixed mode of quantitative and qualitative research had conducted by involving a number of respondents and stakeholders conducted during the year. Several competitiveness factors needs to be upgrading in responding to such policies. The uniqueness and shades of cultural design and creative human resources are essential in enhancing the competitiveness. In addition, the government also expected to participate in the effort to help make patent craft products to keep the rights of the artisans that also create business opportunities and work for local communities. In addition, local governments expected to help improve the ability of artisans by providing training related to improving the quality of craft production along with the diversity of designs that charged with local culture. However, the government expected to strengthen efforts to promote a distribution site that can facilitate purchase access to tourists.
\end{abstract}

Keywords: Competitiveness; Batik-Craft; Image, Shades Local Culture; Creativity 


\section{Introduction}

Not many Indonesian people know Madura craft. Similarly, the people of East Java. Talks about a crafts, it had been dominated by Central Java areas, such as Solo, Klaten, Pekalongan, and others. During this time, Madura is only famous for Salt and Karapan's cow. In fact, Madura Island is one of the centers of batik in Indonesia is no less excited with other areas. In Madura, batik is a hereditary heritage, with works that have high artistic value. The expressive character is a reflection of the character of Madurese people that are free expression, firm, hardworking, tenacious, and candid.

Gentongan crafts that found in Tanjung Bumi, Bangkalan, at the artisan level alone can reach USD 74 per share. The specialty of this batik, the longer the color becomes brighter. It shows that the craft industry in Madura is potential economically. Every day there are thousands of pieces of batik cloth produced from the areas ranging from western to most eastern Madura. The operation of Suramadu since June 9, 2009 and inauguration of batik as world cultural heritage from Indonesia by UNESCO is a good enough opportunity for the home industry actor (Cahyani, 2018). Moreover, the challenge that batik industry - local governments needed addressing is the enactment of the ASEAN-China Free Trade Agreement (ACFTA) from 1 January 2010. In the face of ACFTA, many parties, especially from Indonesia, are anxious, as well as this agreement implemented, so many domestic economic actors are paranoid against Chinese commodity raids (Ananda, 2017; Erdiyansyah, 2018).

In addition to having many variations on products, China is also able to reduce production-distribution costs as efficiently as possible to reduce product prices as low as possible. The implementation of ACFTA can reduce the barriers of trade flow and investment among member countries. Because, there is agreement on Common Effective Preferential Tariff (CEPT) and in ACFTA. The core of CEPT in the ACFTA agreement is the reduction of import tariffs and the elimination of non-tariff barriers to trade in the scope of ASEAN and China. This enables member countries to be distribution-costs that are more efficient. As a result, the price of imported products, especially from China, is much cheaper than domestic products. This leads to unfair competition, and followed by the sluggishness of the domestic business world. The sluggishness of the business world has caused unfavorable foreign investors. In fact, it is not impossible for local industry players to switch professions into import service providers. Therefore, the local government must be responsive and progressive in responding to these economic opportunities and challenges (Ananda, 2017; Devadason, 2010).

This study aim is to respond ACFTA - CEPT by finding out the existing and expected competitiveness of batik handicraft tourism in Madura.

\section{Literature review}

\subsection{Batik Handicraft}

Culture is one of the most important elements for the life of the community, which is hereditary to the diversity of cultural wealth of batik craft. The craft is the art of ancestral heritage in the form of images of cloth for clothing that became one of the culture of the kings of antiquity. 
Each batik-craft made in each region have different shades and characteristics (Schulte-Holthaus, 2018). With the development and production life cycles of the culture industry of a craft, enhances local economic growth. Batik is one form of crafts that characterize and the shades of the region related closely to local culture (Lamusiah, 2018; Chen, Huang, and Wey, 2017).

Various areas of development or training are more diverse. It can compete with the local market. The need for mentoring and counseling on the maintenance of the business (Emelia, 2018; Cahyani, 2018). Image becomes the main thing for tourists about the craft tourism. It becomes the first point that attracted tourists. Furthermore, the uniqueness of a crafts that reveal culture, interpretation, and emotionally influence a way (Hengky, 2014; Gao et al., 2013; Sun, Bhowmick, Nguyen, Tran and Bai, 2011; Chassin, Tetzloff, and Hershey, 1985).

\subsection{Craft's competitiveness.}

The competitiveness of crafts related to market conditions, the level of social development, environmental policy and human resources. Besides, infrastructure quality, technological progress, and other development fields (Navickas and Malakauskaite, 2009). The competitiveness factors include cost efficiency, timely, quality improvement, inventory management, product design and craft design development (Singh, Garg, and Deshmukh, 2007; Girón, Hernández, and Castañeda, 2007; Broadberry and Gupta, 2009).

According to Pearce and Robinson (1997) competitiveness criteria of the craft included: creativity and human resources, excellence in operational oversight, effectiveness of promotional distribution, price advantage and quality of the crafts. There are six factors of handicraft competitiveness: value addition, design uniqueness, new product development, cultural uniqueness, owner's ability to adapt to market trends and raw material quality to innovation in handicraft industry (Cucculelli and Goffi, 2016; Naidu, Chand, and Southgate, 2014).

However, the superiority in the craft's competitiveness includes image (Hengky, 2014, Gao et al., 2013; Sun, et al., 2011), human resource's creativity, promotion effectiveness distribution, price, quality, uniqueness of shades design, new product development (Pearce and Robinson 1997), cultural uniqueness, carefulness reading market trends (Naidu et al., 2014; Singh et al., 2007; Girón et al., 2007; Broadberry and Gupta, 2009).

\section{Methodology}

The mixed mode quantitative and qualitative study (Neuman and Robson, 2014; Ragin, 2014) conducted in Madura from April 10, 2016 to April 25, 2017. 360 Questionnaires distributed in a structured purposive (Meriluoto and Spoof, 2008) distribution to batik artisans, organizations and entities related to the field of handicraft distribution and sales, which include collectors, businesses, suppliers, distributors, merchant association of handicrafts. In addition, the questionnaires distributed over the trade department, tourism department, artisans and home industry owners of batik, cultural, informants from the Department of Industry and Trade Cooperation of Mining and Energy Trade, District Office of Industry and Manpower, traditional markets and supermarkets. 


\section{$\triangle$ Macrothink}

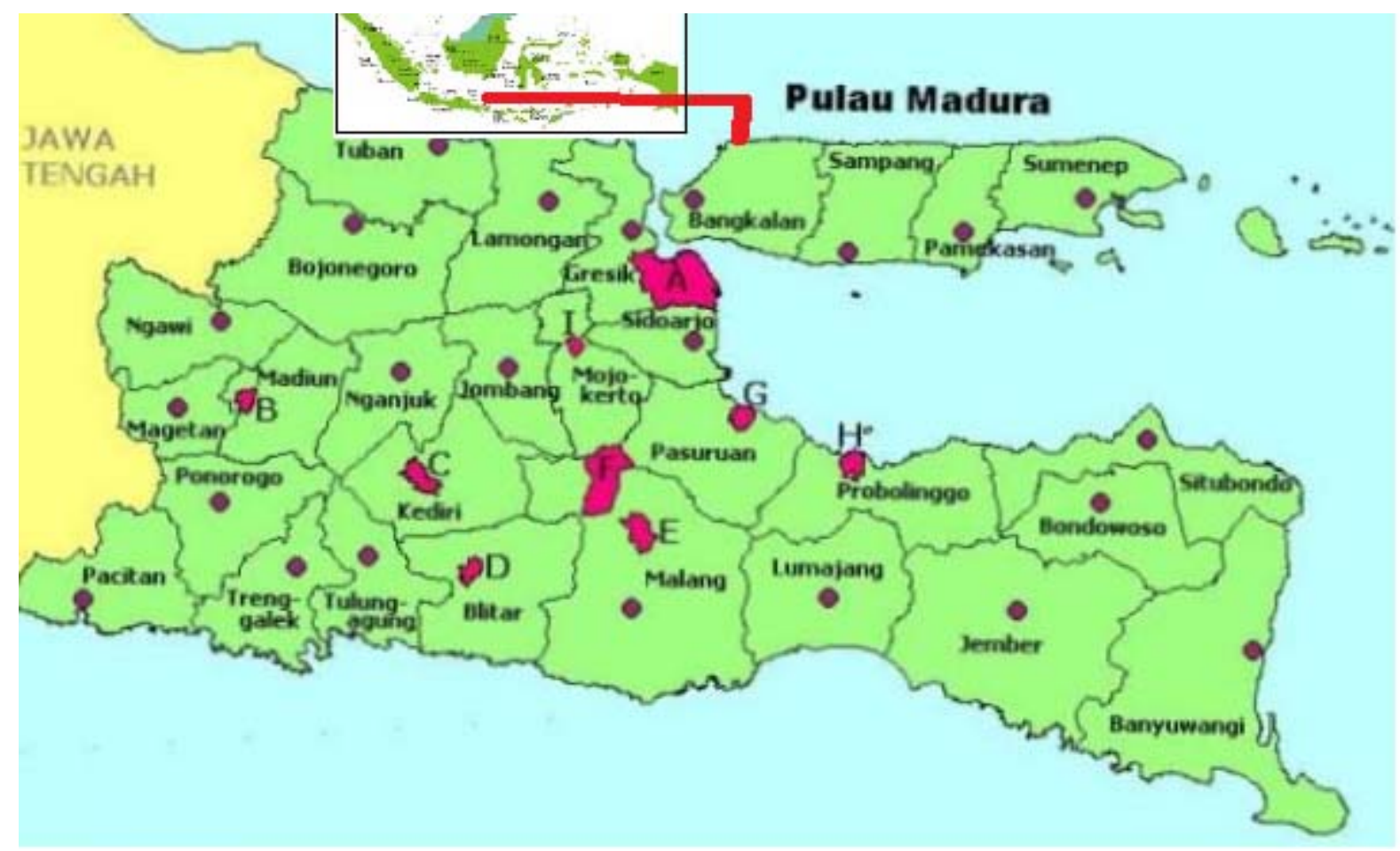

Source:

http://www.josstoday.com/read/2015/10/10/27783/Ketika_Warga_Madura_Ingin_Bentuk_Pro vinsi

Interview using triangulation technique and Focus Group Discussion (FGD). FGDs are pre-defined structured interviews for content analysis led by a skilled moderator. Moderators ask broad questions to get responses and generate discussion about the participants (Boateng, 2012; Onwuegbuzie, Dickinson, Leech and Zoran, 2009; O'Connell and Dyment, 2006; Freeman, 2006; Cameron, 2005).

The tabulation consisting of two parts. Fisrtly, find out the existing competitiveness of the craft, and follow by the expected competitiveness of it. The data collected is tabulated using content analysis - the SAS text miner, which focuses on the competitiveness that included image (Hengky, 2014, Gao et al., 2013; Sun, et al., 2011), human resource's creativity, promotion effectiveness distribution. Besides, it's about price, quality, uniqueness of shades design, new product development (Pearce and Robinson 1997), cultural uniqueness, carefulness of reading market trends (Naidu et al., 2014; Singh et al., 2007; Girón et al., 2007; Broadberry and Gupta, 2009). The result of tabulation of Content analysis (CA) produces a Kappa $(\mathrm{K})$ values (Sim and Wright, 2005). Here is one possible interpretation of K: Poor agreement $=$ Less than 0.20 . Fair agreement $=0.20$ to 0.40 . Moderate agreement $=0.40$ to 0.60 . Good agreement $=0.60$ to 0.80 . Very good agreement $=0.80$ to 1.00 (Sim and Wright, 2005; Thompson and Walter, 1998).

\section{Result and Discussion}

The results of present competitiveness performance tabulation (Table 1) indicate that Madura batik competitiveness is still less competitive $(K=0.3972)$. In terms of a value, there are 


\section{Macrothink}

Journal of Management Research

ISSN 1941-899X 2018, Vol. 10, No. 4

three factors of handicraft excellence today more on cultural uniqueness (value $=36$ ), number of new craft products (28) and competitive prices (26). Currently there are three fusions of competitiveness that are in critical condition, the craft image is still weak (19) and can still be leveling in accordance with the expected performance of competitiveness (Table 2) in the future (27). Similarly, the quality still needs to be improved (28). Similarly, promotion effectiveness distribution still needs to be improved (20). However, there are still very weak of competitiveness factors that need to be improved: creativity of human resources (18) and uniqueness of design shade (20).

Table 1. Existing competitiveness of batik craft in Madura

\begin{tabular}{|l|l|l|}
\hline Existing competitiveness of batik Madura & Value & \% Freq \\
\hline Image & 19 & 0,1329 \\
\hline Human resource's creativity & 6 & 0,0420 \\
\hline Promotion effectiveness distribution & 10 & 0,0699 \\
\hline Price & 26 & 0,1818 \\
\hline Quality & 14 & 0,0979 \\
\hline Uniqueness of shades design & 4 & 0,0280 \\
\hline New product development & 28 & 0,1958 \\
\hline Cultural uniqueness & 36 & 0,2517 \\
\hline
\end{tabular}

Kappa $=\mathrm{K}=0.3972$ 
Table 2. Expected competitiveness of batik craft in Madura

\begin{tabular}{|l|l|l|}
\hline Expected competitiveness of batik Madura & Value & \% Freq \\
\hline Image & 27 & 0,1239 \\
\hline Human resource's creativity & 18 & 0,0826 \\
\hline Promotion effectiveness distribution & 21 & 0,0963 \\
\hline Price & 35 & 0,1606 \\
\hline Quality & 28 & 0,1284 \\
\hline Uniqueness of shades design & 20 & 0,0917 \\
\hline New product development & 33 & 0,1514 \\
\hline Cultural uniqueness & 36 & 0,1651 \\
\hline
\end{tabular}

$\mathrm{K}=0.6056$

Based on tabulation in Table 2, the superiority in handicraft competitiveness could be improving by paying more attention to the uniqueness of design shades and creativity of artisans in making handicrafts. It can improve batik competitiveness in the future. Batik craft has become one of the creative industries in Indonesia. Batik became one of the supporting for the local and national economy. Ethnic designs made based on the history and potential for the region. Production prices expected to increase production to marketing (Nagori and Saxena, 2012).

The current development of creative industries in the Indonesian economy have shown a significant increase. The creative industries in increasing the growth of the Gross Domestic Product (GDP), work events, and national industry. Unfortunately, these improvements are not in line with their internal development. It takes creative people as a resource that can increase competition in Indonesia in the craft industry by reflecting local culture and appreciation through creativity on innovations.

\subsection{Uniqueness of shades design}

Madura craft shade is more than a thousand kinds. The name of the shade related to an image and the way of dying, is consonant with the local language. The names of these shades are Ramo, Banjar Ramo, Rongterong, Perkaper, Rawan, Wood Fibers, Panca Warna, and so on. The craft shade of Madura has its own uniqueness that is not own by some crafts from other areas. The main characteristic or craft is a home-based business that is easy to recognize that there is always a red color in the floral or leaf shade. From some circles to give an assessment, 
there are similarities between batik shades Yogyakarta and Madura. The existence of shade batik cloth is similar. There is a blood relationship between the King of Mataram with the magnifier in Madura itself.

Craft productions experienced the development of color and represents the character of the nation contained in batik shades that cover the responsibilities depicted with clove machete shade. Hard work is on the shades of clove machetes. Fair is on the mangosteen shade. Patience in durian shade, honest on mangosteen shade. Loving the homeland in all batik shades. Fourth, the value of local character of national wisdom based on batik shade is economic and education, as well as artistic, and beauty. It has relationship between the values of character contained in the shade (Zhang et al., 2013).

Furthermore, the strengthening of promotion still needed. Local government is very necessary to support the program to promote batik that contains the values contained in the shade, and make batik as a king of his own home and establish cooperation with other regions. For the artisans and home industry, owners to continue to develop batik should always improve the quality of batik production, and develop batik shades taken from local culture. The people to be proud to wear batik typical of the region.

Traditional craft shaded Madura, East Java, can be extinct, if the artisans and batik entrepreneurs more followed the trend of soft batik shade, i.e., batik shades that tend to be interested in the market lately. Batik shade of soft colors and writing lately is indeed the most demand by tourist's craft. This shade is a kind of batik shade that has not distinguished ethnic between one regions with another region, such as Madura's craft shades, Solo and Yogyakarta. This means soft batik shade is already crossing regional and cross ethnic (Riani, Rum and Rahmawati, 2018).

Crafts on the island of Madura produced evenly in four districts namely Bangkalan, Sampang, Sumenep, and Pamekasan. Bangkalan regency is more known as Tanjung Bumi batik as the name of one village in Bangkalan. In Sampang and Sumenep, there are also batik artisans did not evenly distribute. While, there are nine of 13 districts that became the center of the craft industry in Pamekasan. Madura batik production is much difference between batik products of Solo, Yogyakarta, and other Central Java areas. In the area, batik shades have the character of regularity, stagnant, and developed based on mathematical formulas.

Craft's geometry describes a bureaucracy. It influenced by the palace's tradition of being full of order, systematic, and rigid. In Madura, batik making cling to the coastal batik shade. This coastal batik has a strong character, especially on the coloring and explorative shades. Therefore, batik Madura called with non-geometric batik. Craft has a clear shade, color firm, tacky, expressive, natural, and contains elements of the environment of flora or fauna.

Madura's coastal craft has a striking color as a deep red like a monastery. Madura batik shades non-geometric wing, freer as images of animals, plants, forests and the like. In addition, the craft does not interfere with patterns or mail. The artisan is more imaginative and follows the sensitivity of his soul and his instincts. Thus, it is difficult to find in Madura there are two pieces of batik cloth that has the same results from the same shade. Craft shade is a critical part 
of craft fabric making process itself. Scratches "Canting” and artisan's hand motion involving the mind and heart. So that, it is scratched into the shade that will attract the interest in craft lovers. They can find the beauty of his style and craft's shade of a firm and bold color. Although, it looks rough, it does not mean cheap. The specialty of this craft is the color that the longer it will be brighter.

High competition of craft industry in Central Java with craft from China. Lately, artisans from outside Madura many survive to make the shade and design in accordance with the culture and character of the region. One reason, the original character of coastal batik is not lost. Even though, it has been collaborated with new shades. It is red with a combination of green and yellow, even black makes tourists more interested to have it. Such colors are very challenging and anti-mainstream. Coastal craft in Madura of which has a natural shade and environment. Like the shade Sesse '(skin of sea fish), Ramok (root), Ketupat and potted flowers. There are also traditional shades such as Tanahan Sekar Jagad, Tanahan Oleng (winding ground), Mo'ramok Land (rooted land), Rice Kepak (empty grain), and fruits such as Balinese bananas.

The shades continue to be developing into contemporary batik. It mixed with shades built on the imagination of artisans. This kind of batik development that will obscure the authenticity of Madura coastal batik shaded. Therefore, the government expected to provide additional insight to batik crafters. They did not eliminate the basic shades. If already lost the basic shade, will be annexing easily and claimed by other nations (Wisudawati and Maheswari, 2018).

Some villages in Bangkalan Madura such as Burneh, Ketengan and Tanjung Bumi became craft centers. The three villages are very famous beauty crafts. It has a very high artistic value rather than batik cap that uses a stamped or printed machine. While, it was doing by hand. This batik work usually takes a longer time. Especially if the shades and details of batik work are quite complicated. Sumenep craft has a characteristic that is the shade of Chicken and red color that characterizes Madura batik in general. As for the color consists of two kinds, namely: Synthetic / Chemical Dyes - natural dyes such as from Mohani acacia leaf teak and others. City Batik is generally brightly colored. This attributed to the mentality of the Bangkalan people that are located in the open and bold coastal areas.

\subsection{Image}

Madura craft color is usually dominating by the impression or image of bold colors, such as red, yellow, green. Craft is not just a story about the dimensions of beauty, not just an inheritance to an impression. It contains the meaning of perseverance, diligence and prosperity. Then craft has an important meaning to show the seriousness of local governments in the success of the program. Craft makes the impression of luxury and fashionable, and vice versa, soft colors give the impression or image of classical and soft (Gausel and Leach, 2011).

Madura artisans plant to develop shade design with three-dimensional or three beautiful shades. Craft's fabric presented three-dimensional ornaments or three shades on a sheet of cloth. The typical craft shade of a bright yellow red color display with a charming black base. Courage craft that uses bright colors gives the impression sweet and cheerful for the wearer.

The arrangement of craft shades, textures, and glamorous golden colors from weaving tapis. 
Geometric shades of the filter, such as pyramids and zigzag patterns, hold a modern and futuristic hidden impression. Unique color matches look attractive, between the soft natural colors of the craft and bright colors of synthetic materials. The overall impression or image of the collection is cheerful (playful), fresh, unique, futuristic, as well as supple (Joly et al., 2014).

\subsection{Human resource's creativity}

Creative economy has grown rapidly in the world as well as in the nation of Indonesia. The economy has a new concept in the current era, namely an information and creativity developed by relying on the idea of Human Resources (HR). Creative Economy also consists of many parts that concerned such as Advertising, Architecture, Crafts, Product Design, and Fashion. No less creative-innovative handicrafts became one of the most creative industries in Madura. Handicrafts are still very much an alternative or a choice of local people to satisfy and please, especially the unique handicrafts are unique and different, supported by many of its natural resources (Astuty and Suryana, 2018; Gumulya and Amanda, 2018).

So that, craft can be one of the handicraft that can become a very profitable creative industry economy (Hidayat, 2018). It is very famous. Currently, craft is still one of the alternative and people's choice to attend formal invitations or formal events. They have to wear neat and polite clothes. Many people use craft. Its shade is diverse and timeless by the changing times. Craft made with patience and patience. Artisans take a long time, the main ingredients in making craft are fabric and "Canting."

\subsection{Promotion effectiveness distribution}

The marketing of craft products of Pamekasan, Madura, East Java, is still vicissitudes. In fact, since last 3 years stagnate. So far only limited to socialization and promotion without any real action from local government. Three years are stuck, only this year is the worst. Local governments are always impressed do not want to be active for intense action. Pamekasan Office of Industry and Trade lacked of spirit in improving craft competitiveness (Jaelani, 2017).

In terms of promotion, the government should also play a role in Madura's sales craft. That is, the government can be a facilitator or mediator between craft manufacturers with tourists on domestically and abroad levels (Damayanti, 2018). As a sales representative, the government needs to carry out its promotion function as much as possible. These strategies can be pursuing in addition expected to use the best possible opportunity, also intended to address the economic challenges that could be a negative implication of the implementation of AFTA and China.

Craft at this time is very easy to find and in the distribution. Even though, its manufacture takes a long time, many we can meet specialty stores that sell craft materials of clothes and accessories. It has now very varied and not just shirt-shaped, but because of the great creativity of Human Resources in Madura. Local community can make it as a dress, blazer, wallet, necklace, pin and other accessories. With that, of course Crafts are of course very influential as a creative economy industry that will generate many advantages. 
As part of the creative industry, craft sequentially develops many areas through the economy. As in Java, artisans have altered their inherited skills into a household-scale industry. Rooting of the cultural heritage, it gradually became an economic based activity in several areas of Java. It has continued to exist on many years and has shown signs of being increasing broadly driven by dynamic developments in technological, aesthetic, functional and economical aspects. The demand for craft products is increasing both from domestic and abroad. The development of artisans triggered to build their home industry into small and medium enterprises.

\subsection{Price}

Prices of Kotah craft's fabrics ranging from USD 10 - 74 per sheet depending on the quality of cotton. Until now Madurese batik has not dared to experiment like an artisan by making fashionable short-sleeved clothes are relaxed and popular community. They still sell in the form of fabric that cut for shirts, blouses, or sarongs. Craft had done for 1 week and sold at a price of USD 4 - 6. While, silk's crafts of Madura done for one to two months, sold for USD 37-74. However, the most expensive-famous for Madura are the Gentongan craft. In ancient times, this process took months to reach almost one year just for a piece of craft. The shade is very complicated and detailed. To get one color only requires soaking at least 6 weeks in a special barrel. Well, the current process of craft still maintained the community Tanjungbumi.

The craft is a typical handicraft Tanjungbumi. Character has a very bright color, variety, and fine workmanship. Most have Malay cyclic shades, Kembang Randu, Ola-ola, Hong birds, Panji Susi, and so forth. It done at least 1 year. The process immersed in a barrel of 6 months after being drawn. So that, it was soaked again for 3 to 4 months. The price of a soft cloth. It can reach up to USD 222. The price depends on the difficulty level of the design and the length of the manufacturing process. Currently it included the most demanded by collectors.

Initially the wives of Tanjungbumi residents make craft filling the spare time. While, they are waiting for their husbands to go home to sea. In the village, there are at least 900 artisans. Teenagers in this village are adept at making batik (Emelia, 2018). The tourists can take the time and take the courage to learn batik. The inhabitants of them happily and patiently to teach them by providing cloths that have available shades together with"Canting" and liquid wax. No need to fear wrong because of the available cloth samples. They will be transferring only to the fabric ready to sell after quite adept.

\subsection{Quality}

In terms of quality, craft should meet quality standards and follow the trend of demand on the global market. This is where the values of culture and creative knowledge become the determinant of its marketing success. Emotions play an important role in the actual and perceived experience of craft products. Emotions govern the quality of interaction with craft products of a tourist environment and deal directly with their assessment of experience.

It is crucial to artisans having approach that focus on tourists' demands. It increased their attractiveness in the development of new craft products. It must meet their physical quality requirements and psychological needs. Furthermore, they say that it takes a long time to work on the craft strands that vary. A regular quality craft completed at most one week. Meanwhile, it 
takes about a month to work it to completion for a medium-quality craft.

For special quality of a craft, it can take several months or even up to a year to do it. In terms of shade and quality, the production of Kotah craft did not inferior compared to the Blue Telaga craft that located in District Tanjungbumi, Bangkalan, and Pamekasan. In fact, the Telaga Biru artisans often order them. The main point indicated that their qualities of it is smoother. Nevertheless, the orders they send are very limited. They did not have the capital to support higher demands. It shades and colors are almost the same as Madura craft generally. Flower and bird shade most dominant with red and green. It drew on cotton cloth. Pamekasan craft industry does not produce on a large scale but provides quality assurance. They can get it in all batik outlets in Pamekasan.

\subsection{New product development}

Around the year 1960-1965 almost all artisans, especially in the village of West Pekandangan Kecamatn Bluto are no longer in production. This is due to the economic recession that hit the country. In 1970, they began to be active again. At that time, one of Sumenep residents that concerned with Batik Tulis continue the efforts of his parents. In 1977, he developed a Sumenep craft business (Bakas, 2015). This business developed until now. With this incident, the government needs a lot of role in stimulating the increase in batik production by training program to increase their skill (Haryadi, 2018). Their industries need to be encouraged. Equally important is to provide the touches of innovation by utilizing advanced technology (Maninggar and Hudalah, 2018). The government also needs to solve the problem of lack of capital. This is the most acute problem facing home-based artisans in Madura. They are generally the poor, who lack access to conventional financial institutions that require collateral in lending capital.

The craft based on the cultural distinctiveness of the community that had been inheriting from antiquity. However, it has different properties in design, development, caused by the interaction of global market ideology. Meanwhile, traditional crafts, involving practices designing it in the root of local knowledge and accumulate over time. They are part of their cultural heritage and deserve to be preserved. They can bridge the gap between ideas and connecting artistic and creative elements.

\subsection{Cultural uniqueness}

Madura craft grew as the development of Sumenep kingdom in the 17th century until the 18th century. Sumenep Kingdom ended in 1926-1929 under the authority on Ario Prabuwinoko. After that, a Bupati led the Sumenep government transfer administration from the kingdom to the Regency has no effect on the existence of Batik Tulis Sumenep.

Madura batik cloth began to know to the wider community in the 16th century and 17 since the time of the kingdom. The story began, as there was a war in the area of Pamekasan Madura. The battle between Ke 'Lesap and Raden Azhar (Kiai Penghulu Bagandan). Raden Azhar is a spiritual advisory cleric Adipati Pamekasan who has the name Raden Ismail or Adipati Arya Adikara IV. While, Ke'Lesap is the original son of Madura descendant of Cakraningrat with concubine wife. 
Raden Azhar wearing craft of magnificence Parang shade or in the language of Madura commonly called the shade Leres cloth with symmetrical transverse shades in the war. Raden Azhar looks to have charisma and looks dashing. He wore a Parang designs shade. Since then, this type of craft has become a conversation with Madurese communities, especially the big men in Pamekasan.

In Yogyakarta and Solo, this type of Parang craft cloth is the king's great clothes. It is said, those who ordinary people abstinence wore them. Recently, the origin may did not use it, as they attend the meeting with the king. For example, it used to invite or attend the meeting. Prominent community figures that introduce craft to Madura are a Duke of Sumenep, Arya Wiraraja, which is none other than Raden Wijaya's close ally, as the founder of Majapahit kingdom.

Craft is part of the wealth treasures of the nation. Its variety of types and batik shades is an indicator that is a heritage, which has been entrenched in Indonesian society. In fact, UNESCO has set the craft of Indonesia as a Humanitarian Heritage for Oral and Nonbendawi Culture since October 2, 2009. In spite of the increasingly passionate, the owner of craft's industry in Pamekasan today had to reinforce the history that it is part of the culture local communities. There is no harm in cultural tourism to any tourists that visit that destination. Visit the craft industry centers directly, such as artisans who live in Klampar and Toket villages in Proppo sub-district, Toronan village, Kowel sub-district or they can go to Banyumas village.

The existence of Sumenep Regency to be the fortress of Madura culture, which can see from the remnants of the greatness of Sumenep crafts. It stamped on a number of ancient buildings and crafts of the people, one of which is a craft Sumenep. The existence of craft has existed on long, as well as some places that become centers of traditional handicrafts such as in Java, Cirebon, Garut, Solo and Yogyakarta, Pekalongan, Pacitan Palembang and Jambi.

In Madura itself, making craft is a culture passed down from generation of generation. The style and variety is so free and unique. One piece of batik cloth made with individual skill in unit cloth. Even today, they still maintain the traditional way of making it written using natural coloring materials that are environmentally friendly.

Madura craft has many pull lines of one design. Variety of shade taken from the shades of plants, animals, and shades combination of artisan's creations. It consists of various shades craft according to the area. Craft of the coast has bold shades and colors. While, the inland craft is classic and tends to dim color. This related to the nature of coastal communities that are open to outside cultural influences. Another characteristic of the craft is the number of lines emblazoned in one design. Each craft design also has a story each that describes the daily life of the people of Madura.

\section{Conclusions}

The competitiveness of craft in Madura needed to enhance by increasing the effort of artisans in responding to the ACFTA-CEPT challenge. It is about to increase the creative human resources in exploring and exploiting the uniqueness of local culture potential. All of that poured in the design of the craft in assisting in the promotion of effective promotion with 
distribution networks that support sales and marketing craft.

In addition, the government should assist craftsmen with training to improve the quality of production and finishing craft and make patent rights that can help to keep the craftsmen's rights, as well as the artist's craft collection design shades that cheerful, fresh, unique, and futuristic.

\section{Implication}

The artisans recommended trying to improve their shaded design by inserting a little shades of Madura craft by adding a bold colored picture. This type of interest element becomes the ethnic identity of the craft. It shades is soft, which is now a trend of market demanded, is actually the third phase in the world market of batik in Indonesia and on an international scale. It would help improve the craft competitiveness in the very near future.

\section{Acknowledgement}

The author like to thanks to SHINE Institute that helped distributing the questionnaires to the respondent. In this good opportunity, author would like to thanks the editors and anonymous reviewers that have supported in the process of publication of the journal.

\section{References}

Ananda, M. (2017). Impact of ASEAN-China Free Trade Area (ACFTA) Cooperation on Indonesian Batik Competitiveness 2010-2016. Jurnal Online Mahasiswa Fakultas Ilmu Sosial dan Ilmu Politik Universitas Riau, 4(2), 1-11.

Astuty, E., \& Suryana, S. (2018). Creative People as a New Source of Competitive Advantage in Creative Industry. Sebelas Maret Business Review, 2(1). https://doi.org/10.20961/smbr.v2i1.13298

Bakas, F. (2015). The importance of investigating the role of gender in tourism's resilience to an economic crisis. Revista Turismo \& Desenvolvimento, (23), 21-35.

Boateng, W. (2012). Evaluating the efficacy of focus group discussion (FGD) in qualitative social research. International Journal of Business and Social Science, 3(7).

Broadberry, S., \& Gupta, B. (2009). Lancashire, India, and shifting competitive advantage in cotton textiles, 1700-1850: the neglected role of factor prices. The Economic History Review, 62(2), 279-305. https://doi.org/10.1111/j.1468-0289.2008.00438.x

Cahyani, I. B. (2018). Exploration of Variety National Cultural Heritage Value in Trenggalek Motif Batik. Bachelor Thesis, Department of Law and Citizenship - Faculty of Social Sciences UM.

Cameron, J. (2005). Focusing on the focus group. Qualitative research methods in human geography, 2, 116-132.

Chassin, L., Tetzloff, C., \& Hershey, M. (1985). Self-image and social-image factors in adolescent alcohol use. Journal of Studies on Alcohol, 46(1), 39-47. 
https://doi.org/10.15288/jsa.1985.46.39

Chen, C.-Y., Huang, H.-H. \& Wey, S.-C. (2017) 'The mediating roles of differentiation strategy and learning orientation in the relationship between entrepreneurial orientation and firm performance, Corporate Management Review, 37(1), pp. 1-40.

Cucculelli, M., \& Goffi, G. (2016). Does sustainability enhance tourism destination competitiveness? Evidence from Italian Destinations of Excellence. Journal of Cleaner Production, 111, 370-382. https://doi.org/10.1016/j.jclepro.2014.12.069

Damayanti, R. (2018). Doctoral dissertation - Accounting information system of cost of goods manufactured by job order costing method at Salamanda craft industry, STMIK AKAKOM Yogyakarta.

Devadason, E. S. (2010). ASEAN-China Trade Flows: moving forward with ACFTA. Journal of Contemporary China, 19(66), 653-674. https://doi.org/10.1080/10670564.2010.485403

Emelia, T. W. (2018). Artisan Pandan mat in the village of Alue O Idi Rayeuk. Jurnal Pengabdian Kepada Masyarakat, 24(1), 551-555.

Erdiyansyah, A. (2018). Doctoral dissertation, Relationship Marketing Analysis on The Large Cost Of Craft And Batik Yogyakarta,, Universitas Teknologi Yogyakarta

Freeman, T. (2006). 'Best practice'in focus group research: making sense of different views. $\begin{array}{llll}\text { Journal of } \quad \text { nursing, 59anced } & \text { 46(5), }\end{array}$ https://doi.org/10.1111/j.1365-2648.2006.04043.x

Gao, Y., Wang, M., Zha, Z. J., Shen, J., Li, X., \& Wu, X. (2013). Visual-textual joint relevance learning for tag-based social image search. IEEE Transactions on Image Processing, 22(1), 363-376. https://doi.org/10.1109/TIP.2012.2202676

Gausel, N., \& Leach, C. W. (2011). Concern for self - image and social image in the management of moral failure: Rethinking shame. European Journal of Social Psychology, 41(4), 468-478. https://doi.org/10.1002/ejsp.803

Girón, J. D. L. P. H., Hernández, M. L. D., \& Castañeda, M. C. (2007). Strategy and factors for success: The mexican handicraft sector. Performance Improvement, 46(8), 16-26. https://doi.org/10.1002/pfi.154

Gumulya, D., \& Amanda, L. (2018). Search Identity of Gentur Cianjur Lighting Design With Semiotic Theory Approach. Mudra: Jurnal Seni Budaya, 33(1), 35-47. https://doi.org/10.31091/mudra.v33i1.320

Haryadi, W. (2018). Factors affecting the productivity of the handicraft industry workforce in sambah tailor cooperative villages' Sekongkang under the district Sekongkang West Sumbawa Regency in 2015. Economic and business journals, 1(2).

Hengky, S. H. (2014). Beneficial images: Batik handicraft tourism in Yogyakarta, Indonesia. Business and Economic Research, 5(1), 11-23. https://doi.org/10.5296/ber.v5i1.6760 
Hidayat, S. R. (2018). Innovation of Hand-Drawn Batik in Context of Tourism. Bandung Creative Movement (BCM) Journal. 178-181. https://doi.org/10.2991/bcm-17.2018.33

Jaelani, A., (2017). Event and Festival in Cirebon: Review of Shariah Marketing Mix. https://doi.org/10.2139/ssrn.2967233

Joly, A., Goëau, H., Bonnet, P., Bakić, V., Barbe, J., Selmi, S., ... \& Boujemaa, N. (2014). Interactive plant identification based on social image data. Ecological Informatics, 23, 22-34. https://doi.org/10.1016/j.ecoinf.2013.07.006

Lamusiah, S. (2018). Description of special batik special handicrafts Sasambodi SMK 5 Mataram reserves. Paedagoria | FKIP UMMat, 6 (1), 88-99.

Maninggar, N., \& Hudalah, D. (2018). Low-tech innovation and local economic development: case study the traditional batik industry in pekalongan municipality. Tataloka, 20(1). https://doi.org/10.14710/tataloka.20.1.1-11

Meriluoto, J. A., \& Spoof, L. E. (2008). Cyanotoxins: sampling, sample processing and toxin uptake. In Cyanobacterial harmful algal blooms: State of the science and research needs (pp. 483-499). Springer, New York, NY. https://doi.org/10.1007/978-0-387-75865-7_21

Nagori, N., \& Saxena, K. (2012). Marketing of rural handicraft products through retail format: a synthetic review. Annals of Management Research, 2(1), 45-59.

Naidu, S., Chand, A., \& Southgate, P. (2014). Determinants of innovation in the handicraft industry of Fiji and Tonga: an empirical analysis from a tourism perspective. Journal of Enterprising Communities: People and Places in the Global Economy, 8(4), 318-330. https://doi.org/10.1108/JEC-11-2013-0033

Navickas, V., \& Malakauskaite, A. (2009). The possibilities for the identification and evaluation of tourism sector competitiveness factors. Engineering economics, 61(1).

Neuman, W. L., \& Robson, K. (2014). Basics of social research. Pearson Canada.

O’Connell, T., \& Dyment, J. (2006). Reflections on using journals in higher education: A focus group discussion with faculty. Assessment \& Evaluation in Higher Education, 31(6), 671-691. https://doi.org/10.1080/02602930600760884

Onwuegbuzie, A. J., Dickinson, W. B., Leech, N. L., \& Zoran, A. G. (2009). A qualitative framework for collecting and analyzing data in focus group research. International journal of qualitative methods, 8(3), 1-21. https://doi.org/10.1177/160940690900800301

Pearce, D. G. (1997). Competitive destination analysis in Southeast Asia. Journal of Travel Research, 35(4), 16-24. https://doi.org/10.1177/004728759703500403

Ragin, C. C. (2014). The comparative method: Moving beyond qualitative and quantitative strategies. Univ of California Press.

Riani, A., Rum, S., \& Rahmawati, R. (2018). An Increasing In Productivity and Marketing Of Batik Industry in Sragen, Central Java. Jurnal Riset Ekonomi dan Manajemen, 16(2), 179-188. 


\section{Macrothink}

Journal of Management Research

ISSN 1941-899X 2018, Vol. 10, No. 4

Schulte-Holthaus, S. (2018). Entrepreneurship in the Creative Industries. In Entrepreneurship in Culture and Creative Industries (pp. 99-154). Springer, Cham. https://doi.org/10.1007/978-3-319-65506-2_7

Sim, J., \& Wright, C. C. (2005). The kappa statistic in reliability studies: use, interpretation, and sample size requirements. Physical therapy, 85(3), 257-268.

Singh, R. K., Garg, S. K., \& Deshmukh, S. G. (2007). Interpretive structural modelling of factors for improving competitiveness of SMEs. International Journal of Productivity and Quality Management, 2(4), 423-440. https://doi.org/10.1504/IJPQM.2007.013336

Sun, A., Bhowmick, S. S., Nguyen, N., Tran, K., \& Bai, G. (2011). Tag - based social image retrieval: An empirical evaluation. Journal of the Association for Information Science and Technology, 62(12), 2364-2381. https://doi.org/10.1002/asi.21659

Thompson, W. D., \& Walter, S. D. (1988). A reappraisal of the kappa coefficient. Journal of clinical epidemiology, 41(10), 949-958. https://doi.org/10.1016/0895-4356(88)90031-5

Wisudawati, N. N. S., \& Maheswari, A. I. A. (2018). Potential of Silver Craft Product through to Community-Based for Tourism Sustainability in Celuk Village. International Research Journal of Management, IT and Social Sciences (IRJMIS), 5(1), 9-15. https://doi.org/10.21744/irjmis.v5i1.588

Zhang, X., Zhao, X., Li, Z., Xia, J., Jain, R., \& Chao, W. (2013). Social image tagging using graph-based reinforcement on multi-type interrelated objects. Signal Processing, 93(8), 2178-2189. https://doi.org/10.1016/j.sigpro.2012.05.021 